\title{
The Importance of a Sense of University Belonging for the Psychological and Academic Adaptation of International Students in Germany
}

\author{
Hüseyin Hilmi Yildirim, Julia Zimmermann, and Kathrin Jonkmann
}

Department of Educational Psychology, FernUniversität in Hagen, Germany

\begin{abstract}
Although a sense of university belonging has been established as a crucial factor for students' academic success and subjective well-being, little is known about its importance regarding the adaptation of international students in Germany. Likewise, few studies have addressed the long-term reciprocal relations of a sense of university belonging and psychological and academic outcomes. To close this research gap, we analyzed data from $N=3,837$ international students with a set of cross-lagged panel models. The results showed that a high sense of belonging is beneficial for international students' adaptation in Germany as it is related to better well-being, higher study satisfaction, and lower drop-out intention. Furthermore, these indicators of psychological and academic adaption predicted the development of a sense of university belonging across the study entrance period, which points to the dynamic relationship between both kinds of constructs. We discuss the theoretical implications and the implementation of interventions that promote a sense of university belonging to increase the psychological and academic adaptation of international students in Germany.
\end{abstract}

Keywords: international students, sense of university belonging, psychological and academic adaptation, subjective well-being, drop-out intention

Die Bedeutung des Hochschulzugehörigkeitsgefühls für die psychologische und akademische Adaptation internationaler Studierender in Deutschland

Zusammenfassung: Hochschulzugehörigkeitsgefühl gilt als ein kritischer Faktor für den akademischen Erfolg und das subjektive Wohlbefinden von Studierenden, jedoch liegen wenige Erkenntnisse zu deren Bedeutung für die Adaptation internationaler Studierende in Deutschland vor. Um diese Forschungslücke zu schließen, wurden in der vorliegenden Studie Daten von $N=3.837$ internationalen Studierenden mit Cross-Lagged-Panel-Modellen analysiert. Die Ergebnisse zeigten, dass ein hohes Maß an Zugehörigkeitsgefühl vorteilhaft für die Adaptation internationaler Studierende in Deutschland ist, da dieses mit einem höheren Wohlbefinden, höherer Studienzufriedenheit und geringeren Abbruchintentionen verbunden ist. Des Weiteren sagten diese Indikatoren der psychologischen und akademischen Adaptation die Entwicklung des Hochschulzugehörigkeitsgefühls während der Studieneingangsphase voraus, was auf die dynamische Beziehung zwischen beiden Konstruktbereichen hinweist. Abschließend werden theoretische Implikationen und die Umsetzung von Interventionen zur Förderung des Hochschulzugehörigkeitsgefühls mit dem Ziel einer Steigerung der psychologischen und akademischen Adaptation internationaler Studierender in Deutschland diskutiert.

Schlüsselwörter: Internationale Studierende, Hochschulzugehörigkeitsgefühl, psychologische und akademische Adaptation, subjektives Wohlbefinden, Abbruchintention

International students are foreigners who have obtained their university entrance qualification abroad or at a preparatory college (Studienkolleg) in Germany (Statistisches Bundesamt, 2020). Over the last 10 years, the number of international students among newly enrolled students at German universities has increased by around $60 \%$ to 282,002 , with a share of $11.4 \%$ at universities and
$7.3 \%$ at universities of applied sciences (Fachhochschule; DAAD \& DZHW, 2019). Chinese students form the largest group (13.1\%), followed by students from India (6.1\%) and Austria (3.9\%).

While more than $90 \%$ of the international students intend to get a degree in Germany (DAAD \& DZHW, 2019), they often do not succeed. Their drop-out rates 
exceed those of German students, that is, students who have German citizenship and have obtained their university entrance qualification in Germany $(45 \%$ vs. $28 \%$ in the bachelor's programs and $29 \%$ vs. $19 \%$ in the master's programs; Heublein \& Schmelzer, 2018). This is not only problematic for the students themselves, but also for universities and society in general (Petzold-Rudolph, 2018). The identification of factors that affect the academic and psychological adaptation of international students is therefore deemed highly relevant. However, while international students are a thoroughly researched group in other countries (e.g., in the US; see Glass \& Westmont, 2014; Khanal \& Gaulee, 2019; Smith, 2015), few studies have considered their study situation in Germany (Heublein \& Schmelzer, 2018).

Previous research emphasized the importance of a sense of university belonging for the psychological and academic adaptation (e.g., Glass \& Westmont, 2014; Hausmann et al., 2007; Suhlmann et al., 2018) of students. Moreover, a sense of university belonging was shown to buffer academic and social stressors of university life and thus to prevent negative consequences such as depression and burnout (e.g., Walton \& Cohen, 2011). While many students are confronted with stressors related to the transition to university, such as study demands, relocation, separation from family and friends, and the need to make new friends (O'Keeffe, 2013), international students also have to master these challenges in a new cultural context (Bethel et al., 2020; Jindal-Snape \& Ingram, 2013). Hence, a sense of university belonging can be expected to be a particularly important predictor for their academic and psychological adaptation. Conversely, international students' experiences during the early stages of their studies might also predict the longitudinal development of their sense of university belonging. To shed light on this dynamic interplay, we analyzed data of $N=3,837$ international students taking part in the International Student Survey to describe the relationship between a sense of university belonging and academic adaptation (study satisfaction and drop-out intentions) and psychological adaptation (subjective wellbeing, SWB) across the first year of their studies in Germany.

\section{Psychological and Academic Adaptation of International Students in Germany}

The transition to university represents a significant change in young people's lives and brings with it many academic and institutional challenges (De Clercq et al., 2018) as well as personal and social ones, such as leaving the parental home, setting up a new social network, and being on one's own for the first time (Pfund et al., 2020). Of all students who dropped out of their studies, $58 \%$ had considered this decision already in the first two semesters, $44 \%$ made a firm decision to formally deregister in this early period, and $42 \%$ formally deregistered from university (Heublein et al., 2017). These first semesters of degree programs are therefore of particular importance for study success (Gibney et al., 2011; Haarala-Muhonen et al., 2017).

In the case of international students, all of these challenges are even more pronounced since they are accompanied by a cross-cultural transition (Bethel et al., 2020) that often implies language differences ( $\mathrm{Li}$ et al., 2017; Wisniewski, 2018) and changes in the educational system and academic culture (Bethel et al., 2020; MorrisLange, 2017).

In the psychological migration literature, the terms psychological adaptation and academic adaptation are used to describe how well migrants master such challenges in their new cultural environment. The concept of psychological adaptation emphasizes the affective responses to the migration experience. From this perspective, the transition into another culture is viewed as a potential stressor that requires the activation of coping processes. Migrants' psychological adaptation has mostly been researched concerning mental health outcomes and measures of well-being (Leung, 2001; Sam \& Berry, 2010). This study implemented a measure of (hedonic) well-being that has also been established as a useful indicator of depression (Topp et al., 2015). Another perspective on the psychological processes of migration experiences is emphasized by the culture learning approach, which considers the sociocultural aspects of adaptation, i.e., the ability to fit in and effectively negotiate everyday matters in different domains of life within the new cultural context (Sam \& Berry, 2010; Searle \& Ward, 1990). Regarding the sample of university students, the adaptation to the new academic context reflects an important aspect of the sociocultural adaptation (Yu \& Wright, 2016). In line with established models on student success and persistence (Bean, 1980; Pascarella et al., 1983), we considered study satisfaction and drop-out intentions as important indicators of successful academic adaptation. These constructs have also been classified as subjective, process-oriented criteria of study success (Heinze, 2018).

Recent research on the trajectories of migrants' adaptation pointed to substantial interindividual differences in adaptation processes that were, for example, related to individual characteristics and coping resources (Demes \& Geeraert, 2015). With the present study, we add to this 
research by exploring the longitudinal relations between a sense of university belonging and international students' psychological and academic adaptation over the course of the first year of their degree program in Germany.

\section{A Sense of University Belonging and Psychological and Academic Adaptation}

A sense of belonging can be defined as someone's affiliation with their social environment (Arslan, 2018). It is the feeling of being "included, respected, accepted, and supported by others in different social contexts" (Pesonen, 2016, p. 1). In relation to academic institutions, a sense of school and university belonging (Slaten et al., 2016) describes the feeling of being a part of or being affiliated with the campus community (Locks et al., 2008).

There are various theoretical assumptions about how a sense of university belonging affects psychological and academic adaptation. Belonging is considered a fundamental human need and as such its fulfillment is an important condition for well-being (Baumeister \& Leary, 1995). In addition, self-determination theory (SDT; Ryan \& Deci, 2000) posits autonomy, competence, and relatedness as three basic needs, their satisfaction leading to well-being, personal growth, and intrinsic motivation as key conditions for academic success (Niemiec \& Ryan, 2009). A sense of belonging has also been considered as the affective component of school engagement, which predicts adaptive academic behaviors (Fredricks et al., 2004). Finally, the broaden-and-build theory assumes that positive emotions expand people's current thoughtaction repertoire and thus change the way people think, experience, and act, thereby contributing to new ideas and relationships (Fredrickson, 2001). From this perspective, "positive emotions are vehicles for individual growth and social connection" (Fredrickson, 2001, p. 224). This suggests that, on the one hand, a sense of university belonging may indirectly affect academic adaptation via its contribution to well-being. On the other hand, increased well-being may also contribute to the students' sense of university belonging.

Positive associations between a sense of university belonging and psychological and academic adaptation were demonstrated in some previous mostly cross-sectional studies. In a cross-sectional study conducted in Germany, Suhlmann et al. (2018) found that a sense of university belonging was associated with lower intention to drop out and higher well-being. Cross-sectional studies among students in Turkey showed that a sense of university belonging correlated positively with well-being (Karaman \& Tarim, 2018) and university satisfaction (Alkan, 2016; Duru \& Balkis, 2015) and negatively with the intention to drop out (Alkan, 2016).

There are also some studies on the effects of social belonging with a focus on ethnically diverse student samples. A cross-sectional study on international students and refugees in Germany showed that a sense of belonging to the study preparatory course was positively associated with subjective well-being and buffered the negative effect of xenophobia (Grüttner, 2019). In an intervention study with African-American and white students in their first study year, Hausmann et al. (2007) showed that a sense of university belonging predicted the intention to persist beyond other predictors in both groups. Similarly, Hausmann et al. (2009) found indirect effects of a sense of university belonging on the intention to persist and actual persistence via institutional commitment also for both white and African-American students. An intervention study to foster a sense of university belonging among German (92.5\%) and immigrant students $(7.5 \%)$ found that a sense of university belonging mediated the effect of the intervention on depression symptoms in both groups (Marksteiner et al., 2019). For students with a migration background the intervention also seemed to have positive effects on their grades. Similarly, in a longitudinal study, Shook and Clay (2012) found an effect of a sense of university belonging on grade point average for minority students only, whereas in a cross-sectional study grade point average of both international and domestic undergraduate students in the United States was associated with a sense of university belonging (Glass \& Westmont, 2014). Contrary to these findings, Meeuwisse et al. (2010) found an effect of a sense of university belonging on study progress only for majority but not for minority culture students.

To sum up, several mostly cross-sectional studies support the assumption of positive effects of a sense of university belonging on different academic outcomes and well-being, and some suggest that a sense of university belonging might be particularly important for minority students or students with a migration background.

Furthermore, very few studies have considered the reverse effects of psychological and academic adaptation on a sense of belonging to academic institutions (e.g., Tian et al., 2016) despite some theoretical arguments for their prevalence. For example, Fredricks et al. (2004) suggested that the relationship between academic achievement (as another indicator of academic adaptation) and school belonging (as a facet of school engagement) was bidirectional. Motti-Stefanidi et al. (2015) proposed the disengagement hypothesis in the context of the 
academic adaptation of ethnic minority children, which corroborates that low achievement might have detrimental effects on school engagement (and its facet school belonging) as students disengage from school to protect their self-esteem. Regarding effects of well-being on belonging, Amit and Bar-Lev (2015) proposed a model to explain immigrants' sense of belonging to their host countries in which life satisfaction is expected to positively predict belonging. Although none of these theoretical approaches specifically addressed the relationship between psychological and academic adaptation and sense of university belonging among international students, they do suggest that a model that takes both directions of effects into account may add to the current understanding of belonging processes.

\section{The Present Study}

The present study examined the reciprocal relations between a sense of university belonging and psychological (SWB) and academic adaptation (study satisfaction and drop-out intention). While the effects of a sense of university belonging on psychological and academic adaptation have already been investigated outside of Germany for minority students (and in some cases for international students), to the best of our knowledge no studies have investigated these effects among international students in Germany.

In line with previous findings, we expected positive effects of a sense of university belonging on study satisfaction and SWB as well as a negative effect on drop-out intentions. Furthermore, although few empirical findings bolster these assumptions, we expected that study satisfaction and well-being positively predicted a sense of university belonging whereas drop-out intentions were expected to yield a negative effect.

\section{Method}

\section{Sample}

The analyses are based on $N=3,837$ international students in Germany who participated in at least one of the first two waves (t1 and t2) of a panel study (International Student Survey), which was carried out as part of the interdisciplinary research project Academic Success and Withdrawal Among International Students in Germany in Bachelor's and Master's Programs (SeSaBa) that was fund- ed by the Federal Ministry of Education and Research (BMBF).

The online panel survey was aimed exclusively at international students who studied in Germany at the start of data collection in the first semester of a bachelor's or master's degree program and intended to obtain a degree in Germany (Falk et al., 2021). The participants registered for the study by filling in a short questionnaire (t0). This procedure ensured that only participants who had fulfilled the inclusion criteria were admitted to the study. Data collection took place between January and April 2018, i.e., at the end of the first university semester of the surveyed students, and at the end of the first academic year between June and August 2018. The panel survey was carried out in German and English.

The sample represents 133 countries. Indian students make up the largest group in the sample $(12.4 \%, n=476)$, followed by Chinese $(8.9 \%, n=343)$, Syrian $(5.2 \%, n=$ 201), Russian $(4.5 \%, n=173)$, and US-American students $(3.8 \%, n=146)$. The participants were studying at 132 universities in all 16 federal states of Germany and in 36 subject groups. Forty percent were attending a bachelor's and $60 \%$ a master's program. The mean age at $\mathrm{t} 1$ was $M=$ $25.24(S D=4.11) ; 43.9 \%(n=1,684)$ were female.

\section{Instruments}

\section{Sense of University Belonging}

Sense of university belonging was measured with three items of a scale by Bollen and Hoyle (1990, e.g., "I see myself as part of the community of my higher education institution"), using a 5-point Likert scale ( $1=$ strongly disagree to $5=$ strongly agree; $\alpha_{\mathrm{t} 1}=.86$ and $\alpha_{\mathrm{t} 2}=.87$ ).

\section{Study Satisfaction}

An adapted short version of the Study Satisfaction Questionnaire by Westermann et al. (1996) was used to assess satisfaction with study content (e.g., "I find my degree program really interesting"), satisfaction with the study conditions (e.g., "Too little attention is paid to the concerns of students at my higher education institution"), and satisfaction with study burden coping (e.g., "Studying often makes me feel tired and worn out") as subjective dimensions of study success. Each scale consisted of three items with a 5 -point Likert scale $(1=$ strongly disagree to $5=$ strongly agree) satisfaction with study content: $\alpha_{\mathrm{t} 1 / \mathrm{t} 2}=.83$; satisfaction with study conditions: $\alpha_{\mathrm{t} 1}=.67, \alpha_{\mathrm{t} 2}=.63$; satisfaction with study burden coping: $\alpha_{\mathrm{t} 1 / \mathrm{t} 2}=.68$ ).

\section{Drop-Out Intention}

The intention to drop out was assessed with the singleitem measure included in the National Educational Panel 
Study (NEPS): “I'm seriously considering dropping out of my current degree program" (Blossfeld et al., 2011). The response format was also a 5 -point Likert scale $(1=$ does not apply at all to $5=$ fully applies).

\section{Subjective Well-Being}

Subjective well-being was assessed with the WHO-5 WellBeing Index (WHO, 1998). The WHO-5 consists of five items (e.g., "My daily life has been filled with things that interest me"), which are evaluated concerning the last 2 weeks using the following scale: $1=$ at no time to $6=$ all of the time $\left(\alpha_{\mathrm{t} 1}=.88\right.$ and $\left.\alpha_{\mathrm{t} 2}=.87\right)$. The descriptive statistics for all variables are summarized in Table 1.

\section{Control Variables}

Age was calculated from the year of birth of the students and was recorded at t1. Gender $(0=$ male, $1=$ female $)$ and degree type $(0=$ bachelor, $1=$ master $)$ were requested in the registration questionnaire. The degree type teaching qualification $(n=1)$ and the gender other $(n=6)$ were treated as missing values because of the low number of cases. The degree type state examination was assigned to the master category. Previous residence in Germany was assessed at 1 ("Before your current stay in Germany, had you ever lived in Germany for at least 1 month?", $0=n o, 1$ $=y e s)$. In addition, during all subsequent waves students were asked about changes regarding their degree type. The regional groups were created based on the country in which the students obtained their university entrance qualification, according to the regional coding system of the DAAD (DAAD \& DZHW, 2019). The variables were dummy-coded, with Western Europe as the reference category and seven dummy variables: Central and South Eastern Europe, Eastern Europe and Central Asia, North America, Latin America, North Africa and Middle East, Sub-Saharan Africa, and Asia-Pacific. Study-related language skills were assessed at $\mathrm{t} 1$ with a self-formulated item ("My language skills are sufficient to cope with my academic studies") on a 5-point Likert scale (1 = strongly disagree to $5=$ strongly agree).

\section{Statistical Analyses}

The percentage of missing data was between $4.77 \%$ for the drop-out intention at $\mathrm{t} 1$ and $21.27 \%$ for an item of subjective well-being at $\mathrm{t} 2$. While $n=2,816$ individuals $^{1}$ participated at both time points, $n=761$ participated at $\mathrm{t} 1$ only, and $n=260$ participated at t 2 only. To check the selectivity of missing values, we compared individuals who had participated at both $\mathrm{t} 1$ and $\mathrm{t} 2$ with individuals who had participated only at $\mathrm{t} 1$. At $\mathrm{t} 1$, those who did not participate at $\mathrm{t} 2$ had significantly higher drop-out intention $(d=0.25)$, lower satisfaction with study content $(d=$ $-0.19)$, satisfaction with the study conditions $(d=-0.31)$, satisfaction with study burden coping $(d=-0.11)$, and lower self-assessed study-related language skills $(d=$ -0.13). There was also a statistically significant effect for country of origin (Cramer's $V=.12$ ) that was because of a higher likelihood of students from North America to not participate at $\mathrm{t} 2$. There were no statistically significant differences concerning any other region, gender, age, sense of university belonging, and SWB. All participants $(N=3,837)$ were included in the analyses. Multiple imputations of missing data (Schafer \& Graham, 2002) is methodologically superior to conventional pairwise and listwise methods of excluding missing data when data are missing at random and when strong covariates are included in the imputation process (Lüdtke et al., 2007). Therefore, we imputed five data sets using IBM SPSS Statistics (Version 26), including many auxiliary variables in the imputation model (see Table A1 in the Appendix).

To assess the reciprocal associations between international students' sense of university belonging and satisfaction with study content (Model 1), satisfaction with study conditions (Model 2), satisfaction with study burden coping (Model 3), drop-out intention (Model 4), and SWB (Model 5) across the first year of their studies in Germany, we specified cross-lagged panel models using Mplus Version 7 (Muthén \& Muthén, 1998-2015). In all models, age, gender, degree type, study-related language skills, previous residence in Germany, and region of origin were controlled. The pooled results of all five data sets are reported. The data and scripts for the main analyses are available at https://osf.io/4gv26/.

\section{Results}

At both measurement occasions, international students' sense of university belonging $\left(M_{t 1}=3.83, S D=0.83 ; M_{t 2}=\right.$ $3.74, S D=0.87)$, satisfaction with study content $\left(M_{t 1}=\right.$ 4.02, $\left.S D=0.78 ; M_{t 2}=3.91, S D=0.79\right)$, satisfaction with study conditions $\left(M_{t 1}=3.36, S D=0.85 ; M_{t 2}=3.29, S D=\right.$ $0.82)$, and SWB $\left(M_{t 1}=3.65, S D=1.05 ; M_{t 2}=3.70, S D=\right.$ 1.02) exceeded the theoretical scale means of 3 . Their satisfaction with study burden coping $\left(M_{t 1}=2.71, S D=\right.$

\footnotetext{
Additional analyses that excluded all participants who participated in only one measurement occasion (i. e., using listwise deletion, remaining $n$ $=2,816)$ produced the same results and confirmed their robustness.
} 


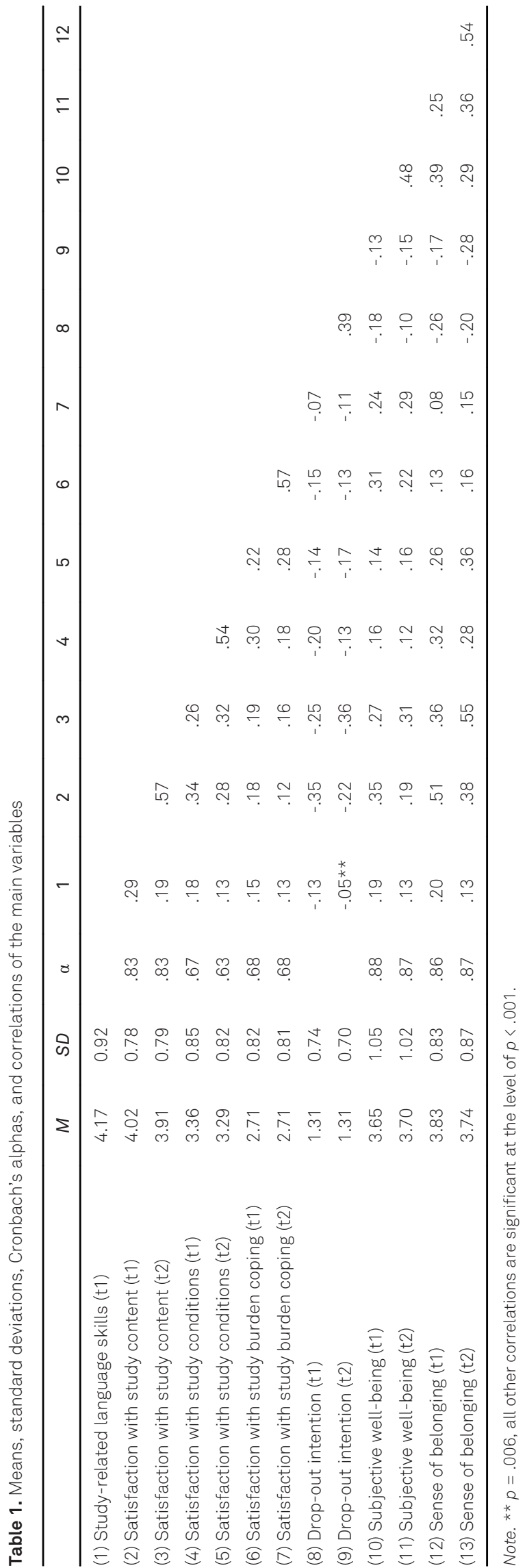

0.82; $M_{t 2}=2.71, S D=0.81$ ) was slightly below the theoretical scale mean and they had very low intentions to drop out $\left(M_{t 1}=1.31, S D=0.74 ; M_{t 2}=1.31, S D=0.70\right)$ (see Table 1). The students also reported high studyrelated language skills $(M=4.17, S D=0.92)$. At both measurement occasions, sense of university belonging was most strongly correlated with satisfaction with study content $\left(r_{t 1}=.51 ; r_{t 2}=.55\right)$.

Figures 1-5 show the standardized coefficients for the cross-lagged and autoregressive paths in the models as well as the correlations within timepoints. The first model explained $31.1 \%$ of the variance in sense of university belonging $\left(R^{2}=.31, p<.001\right)$ and $33.5 \%$ of the variance in satisfaction with study content $\left(R^{2}=.34, p<.001\right)$ at $t 2$. The autoregressive paths showed that sense of university belonging $(\beta=.46, p<.001)$ and satisfaction with study content $(\beta=.50, p<.001)$ had intermediate levels of stability from t1 to $\mathrm{t} 2$. In addition, sense of university belonging at $\mathrm{t} 1$ positively predicted satisfaction with study content $(\beta=.10, p<.001)$ at $\mathrm{t} 2$. Likewise, satisfaction with study content at $\mathrm{t} 1$ positively predicted sense of university belonging $(\beta=.14, p<.001)$ at $\mathrm{t} 2$. Regarding the covariates, gender with higher scores for males $(\beta=-.06$, $p<.001)$ and belonging to the regional group Sub-Saharan Africa $(\beta=.04, p=.049)$ predicted sense of belonging at t2. Age predicted satisfaction with study content $(\beta=.05$, $p=.014)$ at $\mathrm{t} 2$.

The second model explained $30.7 \%$ of the variance in sense of university belonging $\left(R^{2}=.31, p<.001\right)$ and $30.3 \%$ of the variance in satisfaction with study conditions $\left(R^{2}=.30, p<.001\right)$ at $\mathrm{t} 2$. Similarly, satisfaction with study conditions $(\beta=.50, p<.001)$ had intermediate levels of stability from t 1 to $\mathrm{t} 2$. The cross-lagged effects showed that sense of university belonging at $\mathrm{t} 1$ predicted satisfaction with study conditions $(\beta=.10, p<.001)$ at $t 2$ and study satisfaction with study conditions at $\mathrm{t} 1$ had a positive effect on sense of university belonging $(\beta=.11, p<$ .001) at t2. Whereas males had higher sense of university belonging $(\beta=-.06, p<.001)$ at $t 2$, none of the covariates predicted satisfaction with study conditions at $\mathrm{t} 2$.

The third model explained $30.4 \%$ of the variance in sense of university belonging $\left(R^{2}=.30, p<.001\right)$ and $33.3 \%$ of the variance in satisfaction with study burden coping $\left(R^{2}=.33, p<.001\right)$ at $\mathrm{t} 2$. Satisfaction with study burden coping $(\beta=.56, p<.001)$ had intermediate levels of stability from $\mathrm{t} 1$ to $\mathrm{t} 2$ and had a positive effect on sense of university belonging $(\beta=.09, p<.001)$ at $\mathrm{t} 2$. In contrast, sense of university belonging at $\mathrm{t} 1 \mathrm{did}$ not predict satisfaction with study burden coping $(\beta=-.01, p=.603)$ at $\mathrm{t} 2$. Regarding the covariates, gender with higher scores for males $(\beta=-.05, p=.001)$ predicted sense of university belonging at $\mathrm{t} 2$. Belonging to the regional group Central and South Eastern Europe had a negative effect $(\beta=-.05$, 


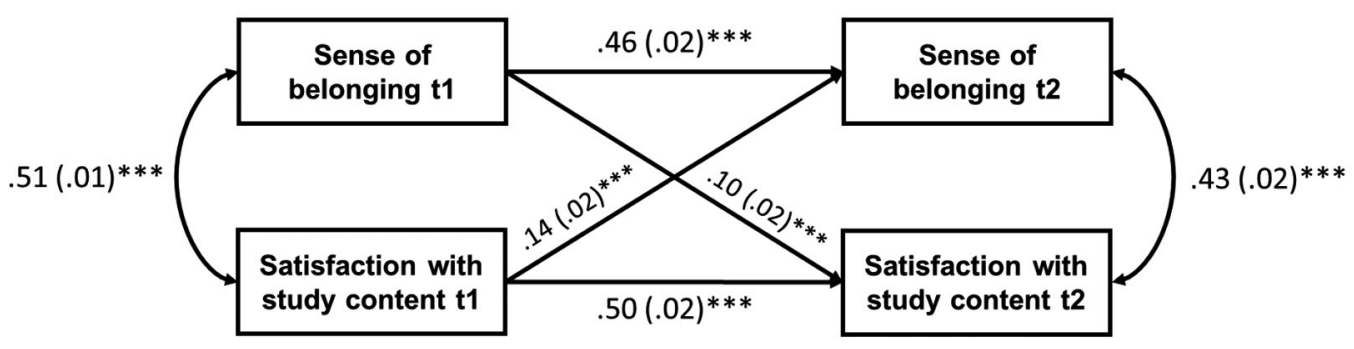

Note. The effects are standardized. Standard errors are given in brackets. ${ }^{\star \star \star} p<.001$.

Figure 1. Cross-lagged model of sense of belonging and satisfaction with study content.

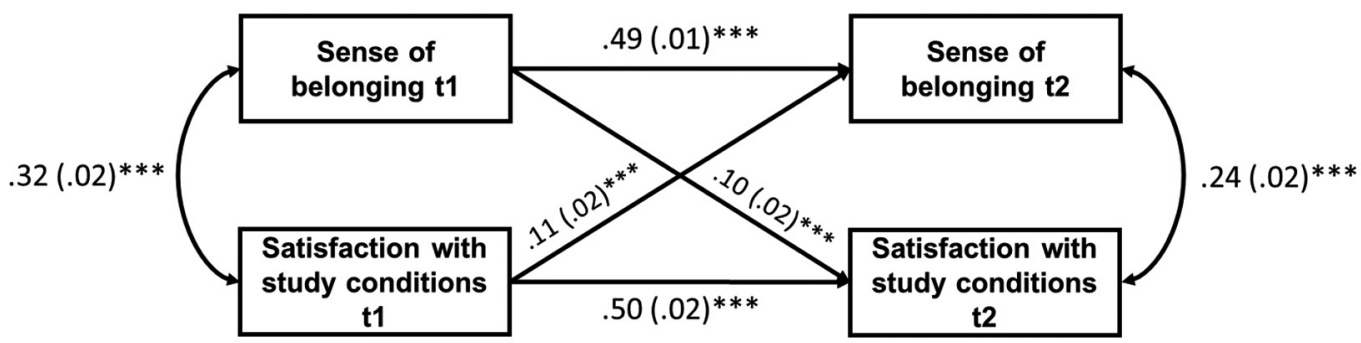

Note. The effects are standardized. Standard errors are given in brackets. ${ }^{\star \star *} p<.001$.

Figure 2. Cross-lagged model of sense of belonging and satisfaction with study conditions.

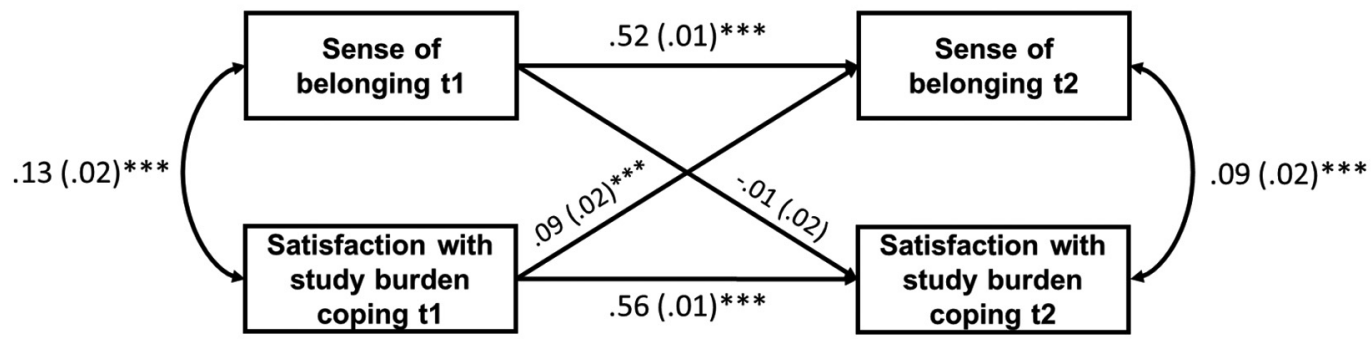

Note. The effects are standardized. Standard errors are given in brackets. ${ }^{\star} \star \star p<.001$.

Figure 3. Cross-lagged model of sense of belonging and satisfaction with study burden coping.

$p=.004)$ and study-related language skills $(\beta=.05, p=$ $.004)$ and studying in the master's program $(\beta=.04, p=$ .014) had a positive effect on satisfaction with study burden coping at $\mathrm{t} 2$.

The fourth model explained $30 \%$ of the variance in sense of university belonging $\left(R^{2}=.30, p<.001\right)$ and $16.3 \%$ of the variance in the drop-out intention $\left(R^{2}=.16\right.$, $p<.001)$ at 2 . Drop-out intention had a rather low level of stability from t1 to t2 $(\beta=.37, p<.001)$. The cross-lagged effects showed that sense of university belonging at $\mathrm{t} 1$ negatively predicted the drop-out intention $(\beta=-.08, p<$ $.001)$ at $\mathrm{t} 2$ and the drop-out intention at $\mathrm{t} 1 \mathrm{had}$ a negative effect on sense of university belonging $(\beta=-.06, p<.001)$ at t2. Males had a higher sense of university belonging ( $\beta$ $=-.06, p<.001)$ at $\mathrm{t} 2$ and bachelor students had higher drop-out intention $(\beta=-.06, p=.003)$ at $\mathrm{t} 2$. The affiliation to the regional group North America $(\beta=-.04, p=.036)$ negatively predicted the sense of university belonging at t2.

The fifth model explained $30.4 \%$ of the variance in sense of university belonging $\left(R^{2}=.30, p<.001\right)$ and $26.1 \%$ of the variance in SWB $\left(R^{2}=.26, p<.001\right)$. The SWB showed an intermediate level of stability from t1 to t2 $(\beta=.42, p<.001)$. Sense of university belonging at t1 positively predicted SWB $(\beta=.07, p<.001)$ at $\mathrm{t} 2$. Conversely, SWB at t1 positively predicted sense of university belonging $(\beta=.10, p<.001)$ at $\mathrm{t} 2$. Males had a higher sense of university belonging $(\beta=-.05, p=.002)$ and SWB $(\beta=-.06, p<.001)$ at t2. Furthermore, the covariates belonging to the regional group North America negatively predicted ( $\beta=-.05, p=.012)$ sense of university belonging at $\mathrm{t} 2$. The degree type at $\mathrm{t} 1$ with higher scores 


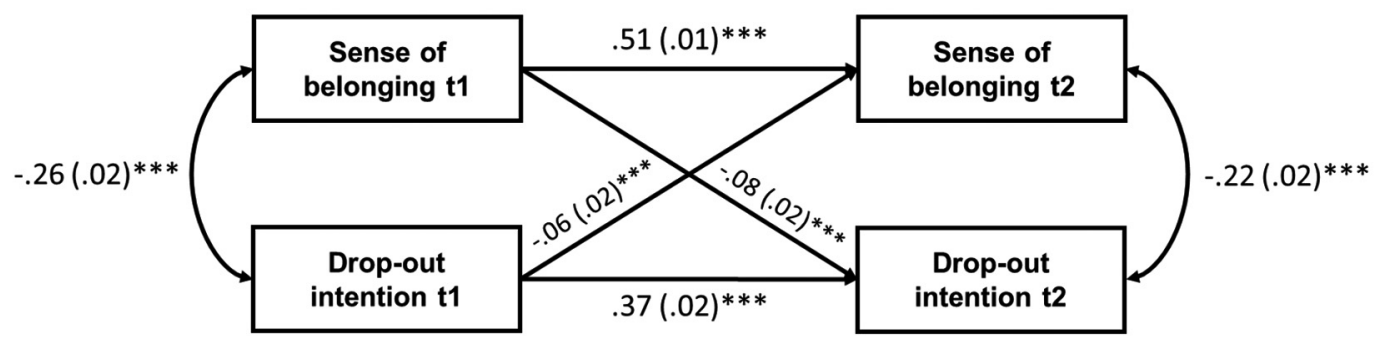

Note. The effects are standardized. Standard errors are given in brackets. ${ }^{\star} \star \star p<.001$.

Figure 4. Cross-lagged model of sense of belonging and drop-out intention.

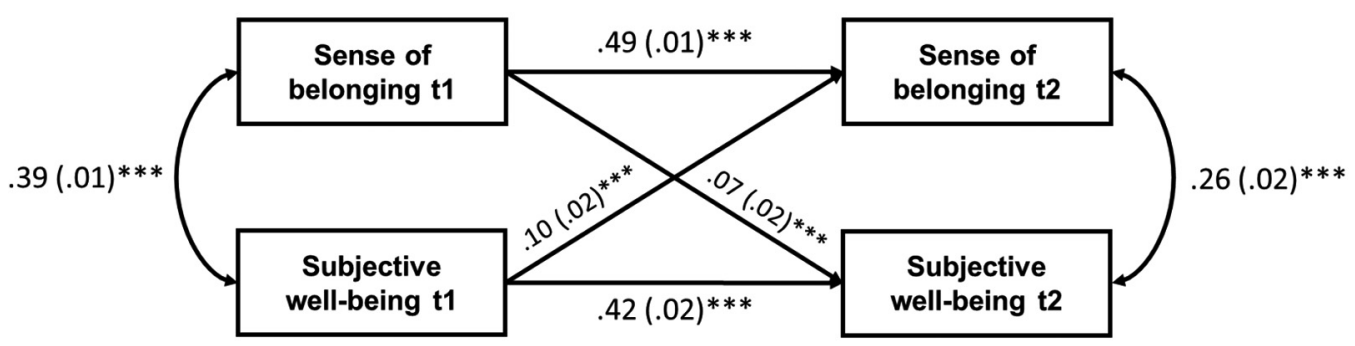

Note. The effects are standardized. Standard errors are given in brackets. ${ }^{\star * \star} p<.001$.

Figure 5. Cross-lagged model of sense of belonging and subjective well-being.

for master students $(\beta=.08, p<.001)$ predicted SWB at t2 and the affiliation to the regional group North Africa and Middle East $(\beta=-.09, p=.001)$ negatively.

If the variables sense of university belonging, satisfaction with study content, satisfaction with study conditions, satisfaction with study burden coping, drop-out intention, and SWB were all included in one cross-lagged model, the results were largely unchanged. Only drop-out intention at $\mathrm{t} 1 \mathrm{no}$ longer had a significant effect on the sense of university belonging $(\beta=-.02, p=.295)$ at $\mathrm{t} 2$. The reverse effect of sense of university belonging at $\mathrm{t} 1$ on drop-out intention at $\mathrm{t} 2$ was also no longer significant $(\beta=-.03, p=$ .092). The only change in the covariates was that gender with higher scores for males $(\beta=-.05, p<.001)$ predicted sense of university belonging at $\mathrm{t} 2$. The other covariates, however, had no significant effect on sense of university belonging at $\mathrm{t} 2$.

\section{Discussion}

The present study examined the relationship between a sense of university belonging and satisfaction with study content (Model 1), satisfaction with study conditions (Model 2), satisfaction with study burden coping (Model 3), drop-out intention (Model 4), and SWB (Model 5) by analyzing data from two measurement occasions across the first year of international students' degree programs in Germany. In contrast to most previous studies that assessed cross-sectional associations between these constructs, the present longitudinal analyses with crosslagged models allowed the (bi)directionality of effects and the stability of constructs to be investigated over time and thus to shed light on the processes of belonging development and the academic and psychological adaptation of international students in Germany.

The autoregressive paths illustrated that both sense of university belonging as well as the investigated indicators of psychological and academic adaptation yielded only intermediate stabilities across the investigated timespan of about 6 months. This finding corroborates the finding that the beginning of a degree program constitutes a dynamic period in which substantial interindividual differences in the development of belonging, study satisfaction, drop-out intention, and well-being occur. Hence, focusing on this dynamic period might be particularly revealing in terms of the investigation of the conditions and consequences of a sense of university belonging as well as regarding potential interventions to improve students' belonging and adaptation.

The cross-lagged paths showed that a sense of university belonging had a positive effect on satisfaction with study content and conditions and SWB and a negative effect on drop-out intention. These results are consistent with the assumptions of the need-to-belong theory (Bau- 
meister \& Leary, 1995) and SDT (Ryan \& Deci, 2000), and they corroborated previous findings on the positive effects of a sense of university belonging on university satisfaction (Alkan, 2016), persistence intentions (Hausmann et al., 2007), and well-being (Karaman \& Tarim, 2018; Suhlmann et al., 2018). Likewise, the study replicated the previously observed negative effect of a sense of university belonging on drop-out intentions (Suhlmann et al., 2018). The present findings closed the research gap regarding the importance of a sense of university belonging for the academic and psychological adaptation of international students in Germany and may thus help to improve the conditions for academic success and wellbeing of this growing student group, e.g., by the development of tailored belonging interventions (for examples, see Marksteiner et al., 2019; Walton \& Cohen, 2011).

The analyses also confirmed the expected reciprocal effects (i. e., positive effects of study satisfaction and SWB as well as a negative effect of drop-out intentions on sense of university belonging) and thus corroborated theoretical approaches that considered academic achievement and well-being as conditions of a sense of belonging (Amit \& Bar-Lev, 2015; Fredricks et al., 2004). Interestingly, the positive effects of satisfaction with study content and with coping with study burden and subjective well-being on sense of university belonging were somewhat stronger compared to the inverse effect of a sense of university belonging on these constructs, while in the other two models the cross-lagged effects showed similar sizes. This points to the importance of study satisfaction (with content and with study burden coping) and well-being for the gradual development of a sense of university belonging among international students and provides a reference point for potential interventions that target the improvement of sense of university belonging. In their meta-analytical investigation of the conditions of a sense of school belonging among adolescents, Allen et al. (2018) also emphasized the interplay of predictors at different levels of analysis (i. e., individual, micro-, and mesolevels). Likewise, studies on the diversity climate of schools showed how distinct institutional approaches to embrace a diverse student body affected the sense of school belonging of ethnic majority and minority students (Schachner et al., 2019). Hence, future research might extend our findings by assessing institutional characteristics that affect sense of university belonging and its longitudinal interplay with academic outcomes and wellbeing among international students.

Another open research question refers to the (indirect) relationships between the investigated variables. For example, sense of university belonging might mediate the effects of study satisfaction on drop-out intentions. However, to thoroughly investigate such questions, we would need measurements from at least three timepoints, which makes these analyses a promising endeavor for further research. Also, should future research consider that, in the current study, psychological and academic adaptation were surveyed using general scales, though there are also cultural transition-specific alternatives (e.g., Brief Psychological Adaptation Scale by Demes \& Geeraert, 2014).

To conclude, our results showed that a high sense of university belonging is an advantage for international students in Germany as it is related to better psychological and academic adaptation. Hence, the implementation of interventions that promote sense of university belonging (Hausmann et al., 2007; Marksteiner et al., 2019; Walton \& Cohen, 2011) and that help to build positive relationships with fellow students (Pittman \& Richmond, 2008) may constitute a promising way to increase the adaptation process of international students and thus the study success of this particular student group. Therefore, since the variables are mutually dependent, interventions to increase well-being (e.g., Friedman et al., 2017) or study satisfaction (for example by providing training in elaborative learning strategies; Yildirim et al., 2020) can also be beneficial to increase the students' sense of university belonging.

In summary, universities should facilitate the special transition of international students with appropriate support and intervention programs to promote student social and academic inclusion and increase well-being. A possible context for corresponding offers in different formats (e.g., online tutorials, peer mentoring, events within the scope of introductory courses) could be the programs for the integration of international students (such as NRWege and Leuchttürme) established at many universities.

\section{References}

Alkan, N. (2016). Psychological sense of university membership: An adaptation study of the PSSM scale for Turkish university students. The Journal of Psychology, 150(4), 431 - 449. https:// doi.org/10.1080/00223980.2015.1087373

Allen, K., Kern, M. L., Vella-Brodrick, D., Hattie, J., \& Waters, L. (2018). What schools need to know about fostering school belonging: A meta-analysis. Educational Psychology Review, 30(1), 1 - 34. https://doi.org/10.1007/s10648-016-9389-8

Amit, K., \& Bar-Lev, S. (2015). Immigrants' sense of belonging to the host country: The role of life satisfaction, language proficiency, and religious motives. Social Indicators Research, 124(3), 947-961. https://doi.org/10.1007/s11205-014-0823-3

Arslan, G. (2018). Exploring the association between school belonging and emotional health among adolescents. International Journal of Educational Psychology, 7(1), 21 -41. https:// doi.org/10.17583/ijep.2018.3117 
Baumeister, R. F., \& Leary, M. R. (1995). The need to belong: Desire for interpersonal attachments as a fundamental human motivation. Psychological Bulletin, 117(3), 497 - 529. https://doi.org/ 10.1037/0033-2909.117.3.497

Bean, J. P. (1980). Dropouts and turnover: The synthesis and test of a causal model of student attrition. Research in Higher Education, 12(2), 155-187. https://doi.org/10.1007/BF0097 6194

Bethel, A., Ward, C., \& Fetvadjiev, V. H. (2020). Cross-cultural transition and psychological adaptation of international students: The mediating role of host national connectedness. Frontiers in Education, 5. https://doi.org/10.3389/feduc.2020. 539950

Blossfeld, H.-P., Roßbach, H.-G., \& von Maurice, J. (Eds.). (2011). Education as a lifelong process: The German National Educational Panel Study (NEPS). Zeitschrift für Erziehungswissenschaft, 14(Suppl. 2), 1-4. https://doi.org/10.1007/s11618-0110198-z

Bollen, K. A., \& Hoyle, R. H. (1990). Perceived cohesion: A conceptual and empirical examination. Social Forces, 69(2), 479 - 504. https://doi.org/10.2307/2579670

DAAD \& DZHW. (2019). Wissenschaft weltoffen: Daten und Fakten zur Internationalität von Studium und Forschung in Deutschland, Fokus: Studienland Deutschland - Motive und Erfahrungen internationaler Studierender [Facts and figures on the international nature of studies and research in Germany, Focus: study destination Germany - Motives and experiences of international students]. http://www.wissenschaftweltoffen.de/ publikation/wiwe_2019_verlinkt.pdf

De Clercq, M., Roland, N., Brunelle, M., Galand, B., \& Frenay, M. (2018). The delicate balance to adjustment: A qualitative approach of student's transition to the first year at university. Psychologica Belgica, 58(1), 67 -90. https://doi.org/10.5334/pb. 409

Demes, K. A., \& Geeraert, N. (2014). Measures matter: Scales for adaptation, cultural distance, and acculturation orientation revisited. Journal of Cross-Cultural Psychology, 45(1), $91-109$. https://doi.org/10.1177/0022022113487590

Demes, K. A., \& Geeraert, N. (2015). The highs and lows of a cultural transition: A longitudinal analysis of sojourner stress and adaptation across 50 countries. Journal of Personality and Social Psychology, 109(2), 316-337. https://doi.org/10.1037/ pspp0000046

Duru, E., \& Balkis, M. (2015). Birey-çevre uyumu, aidiyet duygusu, akademik doyum ve akademik bașarı [The analysis of relationships between person-environment fit, sense of belongingness, academic satisfaction and academic achievement]. Ege Eğitim Dergisi, 16(1), 122 - 141. https://doi.org/10.12984/eed.42566

Falk, S., Thies, T., Yildirim, H. H., Zimmermann, J., Kercher, J., \& Pineda, J. (2021). Methodenbericht zum „International Student Survey“ aus dem Projekt „Studienerfolg und Studienabbruch bei Bildungsausländern in Deutschland im Bachelor- und Masterstudium" (SeSaBa). Release 2 [Methodology report on the "International Student Survey" from the research project "Academic success and withdrawal among international students in Germany in bachelor's and master's programs" (SeSaBa). Release 2].

Fredricks, J. A., Blumenfeld, P. C., \& Paris, A. H. (2004). School engagement: Potential of the concept, state of the evidence. Review of Educational Research, 74(1), 59 - 109. https://doi.org/ 10.3102/00346543074001059

Fredrickson, B. L. (2001). The role of positive emotions in positive psychology: The broaden-and-build theory of positive emotions. American Psychologist, 56(3), 218-226. https://doi.org/10. 1037/0003-066X.56.3.218
Friedman, E. M., Ruini, C., Foy, R., Jaros, L., Sampson, H., \& Ryff, C. D. (2017). Lighten UP! A community-based group intervention to promote psychological well-being in older adults. Aging and Mental Health, 21(2), 199-205. https://doi.org/10.1080/ 13607863.2015.1093605

Gibney, A., Moore, N., Murphy, F., \& O'Sullivan, S. (2011). The first semester of university life: 'Will I be able to manage it at all?' Higher Education, 62(3), 351-366. https://doi.org/10.1007/ s10734-010-9392-9

Glass, C. R., \& Westmont, C. M. (2014). Comparative effects of belongingness on the academic success and cross-cultural interactions of domestic and international students. International Journal of Intercultural Relations, 38, 106-119. https:// doi.org/10.1016/j.ijintrel.2013.04.004

Grüttner, M. (2019). Belonging as a resource of resilience: Psychological wellbeing of international and refugee students in study preparation at German higher education institutions. Student Success, 10(3), 36 - 44. https://doi.org/10.5204/ssj.v10i3.1275

Haarala-Muhonen, A., Ruohoniemi, M., Parpala, A., Komulainen, E., \& Lindblom-Ylänne, S. (2017). How do the different study profiles of first-year students predict their study success, study progress and the completion of degrees? Higher Education, 74(6), 949 -962. https://doi.org/10.1007/s10734-016-0087-8

Hausmann, L. R. M., Schofield, J. W., \& Woods, R. L. (2007). Sense of belonging as a predictor of intentions to persist among African American and White first-year college students. Research in Higher Education, 48(7), 803 - 839. https://doi.org/10. 1007/s11162-007-9052-9

Hausmann, L. R. M., Ye, F., Schofield, J. W., \& Woods, R. L. (2009). Sense of belonging and persistence in White and African American first-year students. Research in Higher Education, 50(7), 649-669. https://doi.org/10.1007/s11162-009-9137-8

Heinze, D. (2018). Die Bedeutung der Volition für den Studienerfolg: Zu dem Einfluss volitionaler Strategien der Handlungskontrolle auf den Erfolg von Bachelorstudierenden [The importance of volition for academic success: On the influence of volitional strategies of action control on the success of Bachelor students]. Springer Fachmedien. https://doi.org/10.1007/978-3658-19403-1

Heublein, U., Ebert, J., Hutzsch, C., Isleib, S., König, R., Richter, J., \& Woisch, A. (2017). Zwischen Studienerwartungen und Studienwirklichkeit. Ursachen des Studienabbruchs, beruflicher Verbleib der Studienabbrecherinnen und Studienabbrecher und Entwicklung der Studienabbruchquote an deutschen Hochschulen (Forum Hochschule 1, 2017) [Between study expectations and study reality. Causes of drop-out, occupational development of drop-outs and development of the drop-out rates at German higher education institutions]. Deutsches Zentrum für Hochschul- und Wissenschaftsforschung (DZHW). https:// www.dzhw.eu/pdf/pub_fh/fh-201701.pdf

Heublein, U., \& Schmelzer, R. (2018). Die Entwicklung der Studienabbruchquoten an den deutschen Hochschulen: Berechnungen auf Basis des Absolventenjahrgangs 2016 [The development of drop-out rates at German higher education institutions. Calculations based on the graduating class of 2016]. Deutsches Zentrum für Hochschul- und Wissenschaftsforschung (DZHW). https://idw-online.de/en/attachmentdata66127.pdf

IBM Corp. Released (2019). IBM SPSS Statistics for Windows (Version 26.0) [Computer software]. IBM Corp.

Jindal-Snape, D., \& Ingram, R. (2013). Understanding and supporting triple transitions of international doctoral students. ELT and SuReCom models. Journal of Perspectives in Applied Academic Practice, 1(1), 17-24. https://doi.org/10.14297/jpaa p.v1i1.39

Karaman, Ö., \& Tarim, B. (2018). Investigation of the correlation between belonging needs of students attending university and 
well-being. Universal Journal of Educational Research, 6(4), 781 - 788. https://doi.org/10.13189/ujer.2018.060422

Khanal, J., \& Gaulee, U. (2019). Challenges of international students from pre-departure to post-study: A literature review. Journal of International Students, 9(2), 560-581. https://doi. org/10.32674/jis.v9i2.673

Leung, C. (2001). The psychological adaptation of overseas and migrant students in Australia. International Journal of Psychology, 36(4), 251 - 259. https://doi.org/10.1080/0020759014300 0018

Li, Z., Heath, M. A., Jackson, A. P., Allen, G. E. K., Fischer, L., \& Chan, P. (2017). Acculturation experiences of Chinese international students who attend American universities. Professional Psychology: Research and Practice, 48(1), 11-21. https://doi. org/10.1037/pro0000117

Locks, A. M., Hurtado, S., Bowman, N. A., \& Oseguera, L. (2008). Extending notions of campus climate and diversity to students' transition to college. Review of Higher Education: Journal of the Association for the Study of Higher Education, 31(3), 257 - 285. https://doi.org/10.1353/rhe.2008.0011

Lüdtke, O., Robitzsch, A., Trautwein, U., \& Köller, O. (2007). Umgang mit fehlenden Werten in der psychologischen Forschung: Probleme und Lösungen [Handling of missing data in psychological research: Problems and solutions]. Psychologische Rundschau, 58(2), 103-117. https://doi.org/10.1026/ 0033-3042.58.2.103

Marksteiner, T., Janke, S., \& Dickhäuser, O. (2019). Effects of a brief psychological intervention on students' sense of belonging and educational outcomes: The role of students' migration and educational background. Journal of School Psychology, 75, 41 - 57. https://doi.org/10.1016/j.jsp.2019.06.002

Meeuwisse, M., Severiens, S.E., \& Born, M. P. (2010). Learning environment, interaction, sense of belonging and study success in ethnically diverse student groups. Research in Higher Education, 51(6), 528-545. https://doi.org/10.1007/s11162-0109168-1

Morris-Lange, S. (2017). Allein durch den Hochschuldschungel. Hürden zum Studienerfolg für internationale Studierende und Studierende mit Migrationshintergrund [Alone through the university labyrinth. Obstacles to academic success for international students and students with a migration background in Germany]. SVR-Forschungsbereich. https://www.svr-migra tion.de/wp-content/uploads/2017/05/SVR_FB_Hochschul dschungel.pdf

Motti-Stefanidi, F., Masten, A., \& Asendorpf, J. B. (2015). School engagement trajectories of immigrant youth: Risks and longitudinal interplay with academic success. International Journal of Behavioral Development, 39(1), 32-42. https://doi.org/10. $1177 / 0165025414533428$

Muthén, L. K., \& Muthén, B. O. (1998-2015). Mplus users guide (7th ed.) [Computer software].

Niemiec, C. P., \& Ryan, R. M. (2009). Autonomy, competence, and relatedness in the classroom: Applying self-determination theory to educational practice. Theory and Research in Education, 7(2), $133-144$. https://doi.org/10.1177/1477878509104 318

O'Keeffe, P. (2013). A sense of belonging: Improving student retention. College Student Journal, 47(4), 605-613.

Pascarella, E. T., Duby, P. B., \& Iverson, B. K. (1983). A test and reconceptualization of a theoretical model of college withdrawal in a commuter institution setting. Sociology of Education, 56(2), 88 - 100. https://doi.org/10.2307/2112657

Pesonen, H. (2016). Sense of belonging for students with intensive special education needs: An exploration of students' belonging and teachers' role in implementing support [Doctoral dissertation, University of Helsinki]. University of Helsinki. https:// helda.helsinki.fi/bitstream/handle/10138/159852/senseofb. pdf?sequence $=1$ \&isAllowed $=y$

Petzold-Rudolph, K. (2018). Studienerfolg und Hochschulbindung: Die akademische und soziale Integration Lehramtsstudierender in die Universität [Academic success and university commitment: The academic and social integration of teacher education students into higher education]. Springer VS. https://doi.org/ 10.1007/978-3-658-22061-7

Pfund, G. N., Bono, T. J., \& Hill, P. L. (2020). A higher goal during higher education: The power of purpose in life during university. Translational Issues in Psychological Science, 6(2), 97-106. https://doi.org/10.1037/tps0000231

Pittman, L. D., \& Richmond, A. (2008). University belonging, friendship quality, and psychological adjustment during the transition to college. Journal of Experimental Education, 76(4), 343-361. https://doi.org/10.3200/JEXE.76.4.343-362

Ryan, R. M., \& Deci, E. L. (2000). Self-determination theory and the facilitation of intrinsic motivation, social development, and well-being. American Psychologist, 55(1), 68-78. https://doi. org/10.1037/0003-066X.55.1.68

Sam, D. L., \& Berry, J. W. (2010). Acculturation: When individuals and groups of different cultural backgrounds meet. Perspectives on Psychological Science, 5(4), 472 - 481. https://doi.org/ 10.1177/1745691610373075

Schachner, M. K., Schwarzenthal, M., van de Vijver, F. J. R., \& Noack, P. (2019). How all students can belong and achieve: Effects of the cultural diversity climate among students of immigrant and nonimmigrant background in Germany. Journal of Educational Psychology, 111(4), 703 -716. https://doi.org/10. 1037/edu0000303

Schafer, J. L., \& Graham, J. W. (2002). Missing data: Our view of the state of the art. Psychological Methods, 7(2), 147-177. https:// doi.org/10.1037/1082-989X.7.2.147

Searle, W., \& Ward, C. (1990). The prediction of psychological and sociocultural adjustment during cross-cultural transitions. International Journal of Intercultural Relations, 14(4), 449 464. https://doi.org/10.1016/0147-1767(90)90030-Z

Shook, N. J., \& Clay, R. (2012). Interracial roommate relationships: A mechanism for promoting sense of belonging at university and academic performance. Journal of Experimental Social Psychology, 48(5), 1168-1172. https://doi.org/10.1016/j.jesp. 2012.05.005

Slaten, C. D., Elison, Z. M., Lee, J.-Y., Yough, M., \& Scalise, D. (2016). Belonging on campus: A qualitative inquiry of Asian international students. The Counseling Psychologist, 44(3), 383 - 410. https://doi.org/10.1177/0011000016633506

Smith, E. W. (2015). Undergraduate international student persistence at a large, public US institution [Doctoral dissertation, University of Tennessee]. University of Tennessee. https:// trace.tennessee.edu/cgi/viewcontent.cgi?article $=4613 \&$ contex $\mathrm{t}=$ utk_graddiss

Statistisches Bundesamt (Destatis) (2020). Bildung und Kultur: Studierende an Hochschulen (Fachserie 11, Reihe 4.1) [Education and culture: Students at higher education institutions]. https://www.statistischebibliothek.de/mir/servlets/MCRFileNo deServlet/DEHeft_derivate_00056740/2110410207004a.pdf

Suhlmann, M., Sassenberg, K., Nagengast, B., \& Trautwein, U. (2018). Belonging mediates effects of student-university fit on well-being, motivation, and dropout intention. Social Psychology, 49(1), 16-28. https://doi.org/10.1027/1864-9335/a0003 25

Tian, L., Zhang, L., Huebner, E. S., Zheng, X., \& Liu, W. (2016). The longitudinal relationship between school belonging and subjective well-being in school among elementary school students. Applied Research in Quality of Life, 11(4), 1269-1285. https:// doi.org/10.1007/s11482-015-9436-5 
Topp, C. W., Østergaard, S. D., Søndergaard, S., \& Bech, P. (2015). The WHO-5 Well-Being Index: A systematic review of the literature. Psychotherapy and Psychosomatics, 84(3), 167176. https://doi.org/10.1159/000376585

Walton, G. M., \& Cohen, G. L. (2011). A brief social-belonging intervention improves academic and health outcomes of minority students. Science, 331(6023), 1447 -1451. https://doi.org/ 10.1126/science.1198364

Westermann, R., Heise, E., Spies, K., \& Trautwein, U. (1996). Identifikation und Erfassung von Komponenten der Studienzufriedenheit [Identifying and assessing components of student satisfaction]. Psychologie in Erziehung und Unterricht, 43(1), $1-22$.

Wisniewski, K. (2018). Sprache und Studienerfolg von Bildungsausländerinnen und -ausländern: Eine Längsschnittstudie an den Universitäten Leipzig und Würzburg [Language and academic success of international students: A longitudinal study at the universities of Leipzig and Würzburg]. Info DaF, 45(4), 573 597. https://doi.org/10.1515/infodaf-2018-0074

World Health Organization. (1998). Use of well-being measures in primary health care: The DepCare Project Health for All. Target 12. E60246.

Yildirim, H. H., Zimmermann, J., \& Jonkmann, K. (2020). Lernerprofile bei Bildungsausländer*innen und längsschnittliche Zusammenhänge mit Studienzufriedenheit und Abbruchintention [Learning profiles of international students and their longitudinal relationships with study satisfaction and drop-out intention]. Zeitschrift für empirische Hochschulforschung, 4(1), 32 - 54. https://doi.org/10.3224/zehf.v4i1.04

Yu, B., \& Wright, E. (2016). Socio-cultural adaptation, academic adaptation and satisfaction of international higher degree research students in Australia. Tertiary Education and Management, 22(1), 49-64. https://doi.org/10.1080/13583883.2015. 1127405

\section{Open Data}

The data and scripts for the main analyses are available at https:// osf.io/4gv26/.

\section{Funding}

The present study was carried out as part of the collaborative research project "Academic Success and Withdrawal Among International Students in Germany in Bachelor's and Master's Programs" (SeSaBa) (DAAD, IHF \& FernUniversität in Hagen). We thank the Federal Ministry of Education and Research (BMBF) for the project funding (funding code: 01PX16016C; funding period: April 1, 2017 to July 31, 2021).

Open access publication enabled by the FernUniversität in Hagen.

\section{Hüseyin Hilmi Yildirim}

Department of Educational Psychology

FernUniversität in Hagen

Universitätsstr. 33

58097 Hagen

Germany

hueseyin-hilmi.yildirim@fernuni-hagen.de

\section{Appendix}

Table A1. Additional variables used to estimate the missing values

Question/Sample item/Description

Motivation for study How important were the following aspects for abroad (t1) your decision to study abroad? Sample item: I'm studying abroad to improve my chances of finding a job and of building my career.

School graduation What kind of higher education entrance qualtype (t1)

Previous study (t1) Have you ever studied (in higher education) in the past, before the program you are studying now?

Study-related value Sample item: Being successful in my studies is beliefs ( $\mathrm{t} 1$ and $\mathrm{t} 2$ )

Expectation of academic success (t1 and t2) very important to me.

In your opinion, how likely is it that you will be able to complete your current study program successfully?

Self-efficacy in studies (t1 and t2)

Sample item: I am usually able to tackle even demanding and complicated tasks effectively.

Regional groups ( $\mathrm{t} 0$ ) Created based on the countries of origin of the international students in accordance with the regional coding system of the DAAD.

Degree type (t2) Which degree are you aiming to obtain with your current study program?

Study-related Item: My language skills are sufficient to cope language skills (t2) with my academic studies.

Study subject groups The study subject groups were aggregated into (t1 and t2) 7 subject groups based on the subject system of the Federal Statistical Office (Statistisches Bundesamt, 2020), whereby the groups sports, art, and others were combined into a residual category based on the number of cases: (1) Humanity studies, (2) Law, economics, and social sciences, (3) Math, natural science, (4) Human medicine-health sciences, (5) Agricultural, forest, and nutritional sciences, veterinary medicine, (6) Engineering, (7) Sports, art, and other studies 